\title{
ゴム配合設計における実験計画法, 回帰分析の利用
}

\section{中 北 一 誠 \\ How to Solve a Trade-off Problem Using the Design of Experiment with Orthogonal Array}

Issei NAKAKITA (Momentive Performance Materials Japan LLC., Sun Mullion NBF 2-6-12 Minamihonmachi, Chuoku, Osaka 541-0054, JAPAN) Issei.nakakita@momentive.com

Designs of experiments with orthogonal array do not only reduce experimental numbers but also can solve treadoff problems. This paper explains how to use this type of DoE to solve trade-off by using model experiment of rubber compound. At first, experiment should be designed by orthogonal array ( L8, L9, L12, L16, etc.) because many factors are needed to solve trade-off problem. Then, contribution \% for all properties of each factors are important. The Trade-off problem will be solved if many factors can be used for the properties having higher \% of contribution. Furthermore, a procedure of multiple regression analysis is explained. It is important to understand some phenomena.

Key Words : Design of Experiment, Orthogonal Array, L8, L9, L12, L16, Trade-off, Multiple Regression Analysis

\section{1. は じ め に}

実験計画法と聞くとおそらく皆さんのイメージは，活用 した方がよいと思っているが計画や解析が面倒であった り，あるいはデータが直接見られないので信用できない， などといったマイナス面のイメージが多く，実際に日頃か ら頻繁に使っている方は少数ではないだろうか.しかし， 今回は実験回数を減らすといったテクニックの話ではな く, 現実的に性能を向上させる手法，具体的には二律背反 を克服する理論的方法として実験計画法を用いた手法を紹 介したい。

この二律背反とは世の多くのエンジニアの方々が取り組 んでいる課題であろう。仮に，単一の機能を持った製品で あったとしても，大きさや，コストといった制約が必ずあ り，こちらを立てればあちらが立たない，といったバラン スを求められることになる，単にバランスではなく，両方 の性能を向上させることができたら，製品の性能が向上す るはずである。

田口立一のいわゆる「タグチメソッド」1）の中で述べら れている寄与率設計法は，まさに二律背反を克服する手法 である。しかし，タグチソットというと，ロバストデザイ ンといった，ノイズに対する安定性という概念は広く知れ 渡っているが，寄与率設計法についてはあまり議論されて こなかったように思う。そこで今回，この寄与率設計法に
ついて紹介したい.

ところで筆者は実験計画法の数学的研究者ではない。長 年ゴムメーカーに勤め, 配合実験を行ってきた，実験計画 法のユーザーである。そこで，ユーザーの立場から，どの ようにしてこの “手法”を利用すればよいのかを，配合実 験の具体例と共に説明する。一方，理論，数式の方は必要 最小限にとどめている。ご専門の方から見れば不備や異論 もあろうかと思う。様々なご指摘をお待ちする。

\section{2. 配 合 実 験 (例題)}

さて, 本誌の読者はゴムの配合経験者が多いと思うので, ゴム配合の実験例をあげて説明してみたいと思う。表 1 に ゴム配合の実験計画を示す，水準 1 が現行配合とする．表 2 に架空の配合実験とデータを示す．実験はランダマイズ して行われているので，実験番号と直交表の列番号とが異 なっている．実験番号 4 が直交表の 1 列, すべての要因の 水準が 1 になるため，現行配合のデータとなる。表 $3 に$ 各

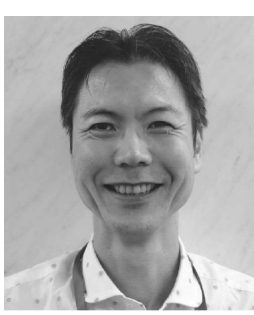

中北 一誠；モメンティブパフォーマンスマテリア ルズジャパン合同会社（大阪/中北阪市中央区南本 町 $2-6-12$ サンマリオン $17 \mathrm{~F})$ シランビジネスマ ーケティング所属アプリケーションデベロップメン トマネージャー。1987 年東京農工大学工学部材料 システム工学科卒業. 同年, 横浜ゴム株式会社入社, 2000 年フレキシス社入社, 2003 年住友ゴム丁業株 式会社入社， 2010 年モメンティブ会に入社，現在 に至る。専門は新規シランカップリング剤の開発・ 企画。 
要因の水準ごとの特性值の平均值を示す．この表から要因 効果図が作成できる。図 1 に未加硫粘度（ML1-4）の要因 効果図を示す，次に各要因の特性值に対する寄与率を計算

表 1 実験計画

\begin{tabular}{llcc}
\hline & 水準 & 1 & 2 \\
\hline $\mathrm{A}$ & SBR 種類 & A タイプ & B タイプ \\
B & BR 量 $(\mathrm{phr})$ & 30 & 20 \\
$\mathrm{C}$ & カーボン量 (phr) & 50 & 60 \\
$\mathrm{D}$ & 液状ポリマー量 $(\mathrm{phr})$ & 0 & 10 \\
$\mathrm{E}$ & オイル量 $(\mathrm{phr})$ & 20 & 10 \\
$\mathrm{~F}$ & 硫黄量 $(\mathrm{phr})$ & 2 & 2.5 \\
$\mathrm{G}$ & 促進剤量 $(\mathrm{phr})$ & 1 & 1.5 \\
\hline
\end{tabular}

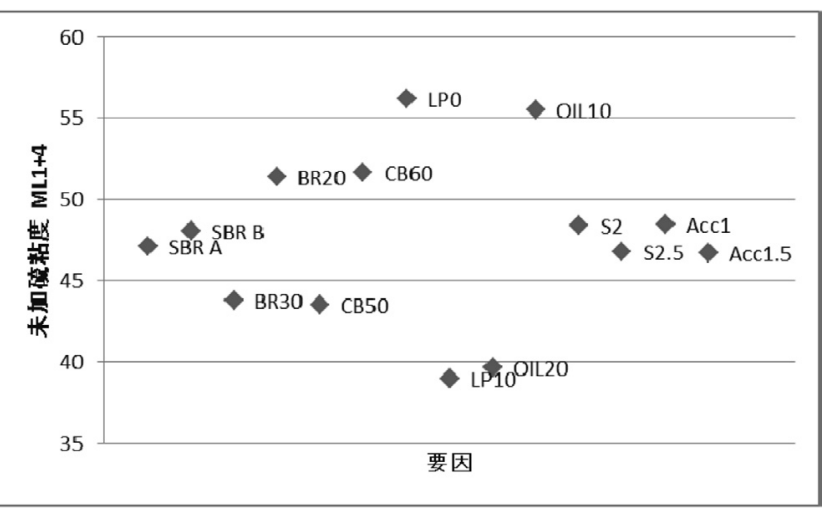

図 1 要因効果図

表 2 実験結果

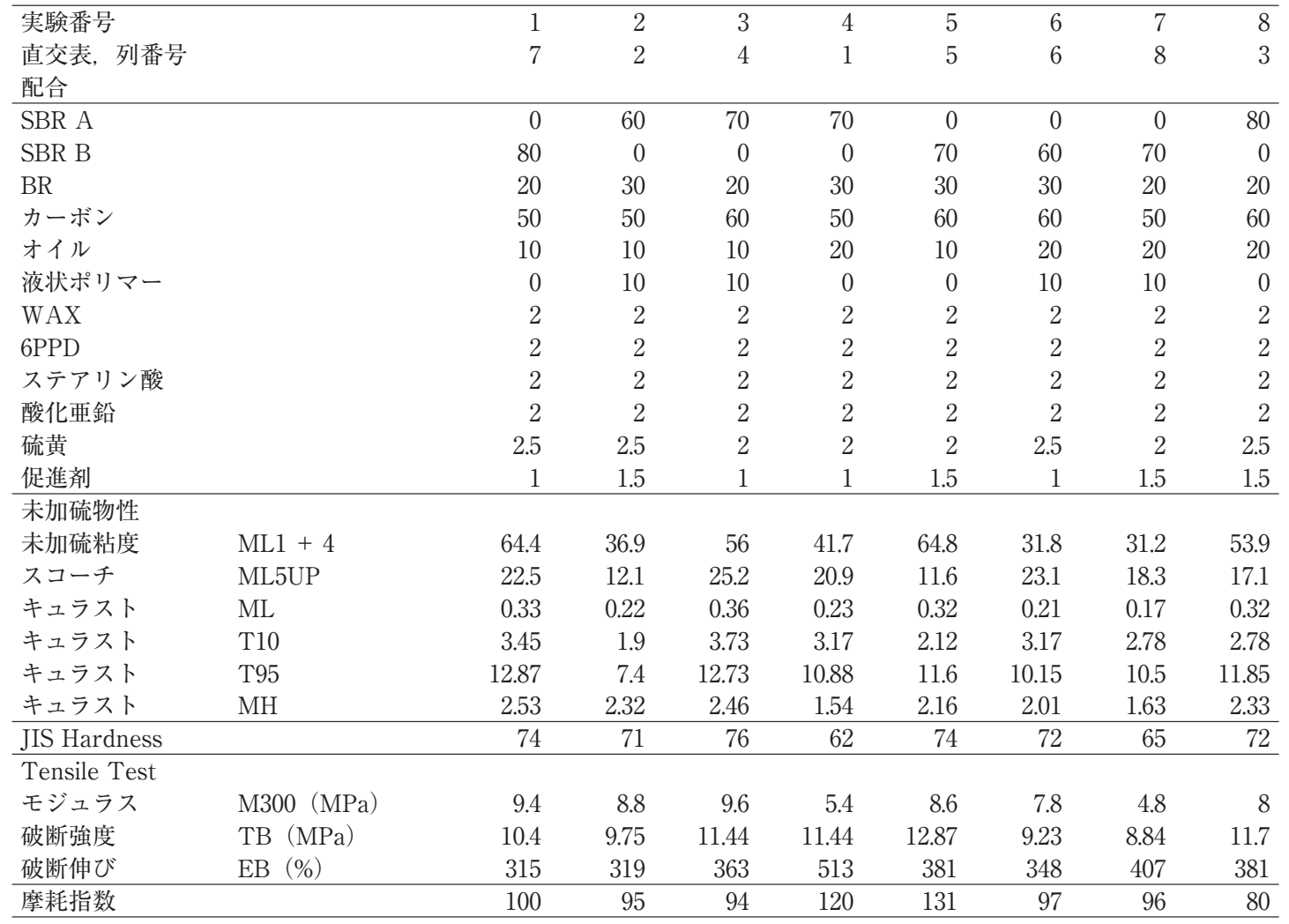

(摩耗指数は值が大きい方が耐摩耗性能が良いことを示す)

表3 各要因の水準ごとの特性值の平均值

\begin{tabular}{|c|c|c|c|c|c|c|c|c|c|c|c|c|c|c|}
\hline \multirow[t]{3}{*}{ 要因 } & \multicolumn{2}{|c|}{$\mathrm{A}$} & \multicolumn{2}{|c|}{$\mathrm{B}$} & \multicolumn{2}{|c|}{$\mathrm{C}$} & \multicolumn{2}{|c|}{$\mathrm{D}$} & \multicolumn{2}{|c|}{$E$} & \multicolumn{2}{|c|}{$\mathrm{F}$} & \multicolumn{2}{|c|}{$\mathrm{G}$} \\
\hline & \multicolumn{2}{|c|}{ SBR } & \multicolumn{2}{|c|}{$\mathrm{BR}$} & \multicolumn{2}{|c|}{ カーボン } & \multicolumn{2}{|c|}{ 液状ポリマー } & \multicolumn{2}{|c|}{ オイル } & \multicolumn{2}{|c|}{ 硫黄 } & \multicolumn{2}{|c|}{ 促進剂 } \\
\hline & A & B & 30 & 20 & 50 & 60 & 0 & 10 & 20 & 10 & 2 & 2.5 & 1 & 1.5 \\
\hline \multicolumn{15}{|l|}{ 未加硫物性 } \\
\hline ML1 + 4 & 47.13 & 48.05 & 43.80 & 51.38 & 43.55 & 51.63 & 56.20 & 38.98 & 39.65 & 55.53 & 48.43 & 46.75 & 48.48 & 46.70 \\
\hline ML5UP & 18.80 & 18.88 & 16.91 & 20.77 & 18.43 & 19.24 & 18.02 & 19.65 & 19.83 & 17.84 & 18.99 & 18.68 & 22.89 & 14.78 \\
\hline ML & 0.283 & 0.258 & 0.245 & 0.295 & 0.238 & 0.303 & 0.300 & 0.240 & 0.233 & 0.308 & 0.270 & 0.270 & 0.283 & 0.258 \\
\hline $\mathrm{T} 10$ & 2.895 & 2.88 & 2.59 & 3.185 & 2.825 & 2.95 & 2.88 & 2.895 & 2.975 & 2.8 & 2.95 & 2.825 & 3.38 & 2.395 \\
\hline T95 & 10.72 & 11.28 & 10.01 & 11.99 & 10.41 & 11.58 & 11.8 & 10.2 & 10.85 & 11.15 & 11.43 & 10.57 & 11.66 & 10.34 \\
\hline $\mathrm{MH}$ & 2.16 & 2.08 & 2.01 & 2.24 & 2.00 & 2.24 & 2.14 & 2.11 & 1.88 & 2.37 & 1.95 & 2.30 & 2.14 & 2.11 \\
\hline JIS Hardness & 70.3 & 71.3 & 69.8 & 71.8 & 68.0 & 73.5 & 70.5 & 71.0 & 67.8 & 73.8 & 69.3 & 72.3 & 71.0 & 70.5 \\
\hline \multicolumn{15}{|l|}{ Tensile Test } \\
\hline M300 (MPa) & 7.95 & 7.65 & 7.65 & 7.95 & 7.1 & 8.5 & 7.85 & 7.75 & 6.5 & 9.1 & 7.1 & 8.5 & 8.05 & 7.55 \\
\hline $\mathrm{TB}(\mathrm{MPa})$ & 11.08 & 10.34 & 10.82 & 10.6 & 10.11 & 11.31 & 11.6 & 9.815 & 10.3 & 11.12 & 11.15 & 10.27 & 10.63 & 10.79 \\
\hline $\mathrm{EB}(\%)$ & 393.8 & 362.5 & 390.0 & 366.3 & 388.3 & 368.0 & 397.1 & 359.2 & 412.0 & 344.3 & 415.8 & 340.5 & 384.5 & 371.8 \\
\hline 摩耗指数 & 97.3 & 106.0 & 110.8 & 92.5 & 102.8 & 100.5 & 107.8 & 95.5 & 98.3 & 105.0 & 110.3 & 93.0 & 102.8 & 100.5 \\
\hline
\end{tabular}

表中のデー夕は有効数字の 1 桁下まで表示している 
する.式（11）にて寄与率の計算式を示す。 ${ }^{2)}$

$$
\begin{aligned}
& C F=(y 1+y 2+\cdots+y 8)^{2} / 8 \\
& S_{T}=y 1^{2}+y 2^{2}+\cdots \cdot y 8^{2}-C F \\
& S_{A}=\left((y 1+y 2+y 3+y 4)^{2}+(y 5+y 6+y 7+y 8)^{2}\right) / \\
& 4-C F \\
& S_{B}=\left((y 1+y 2+y 5+y 6)^{2}+(y 3+y 4+y 7+y 8)^{2}\right) / \\
& 4-C F \\
& S_{C}=\left((y 1+y 2+y 7+y 8)^{2}+(y 3+y 4+y 5+y 6)^{2}\right) / \\
& 4-C F \\
& S_{D}=\left((y 1+y 3+y 5+y 7)^{2}+(y 2+y 4+y 6+y 8)^{2}\right) / \\
& 4-C F \\
& S_{E}=\left((y 1+y 3+y 6+y 8)^{2}+(y 2+y 4+y 5+y 7)^{2}\right) / \\
& 4-C F \\
& S_{F}=\left((y 1+y 4+y 5+y 8)^{2}+(y 2+y 3+y 6+y 7)^{2}\right) / \\
& 4-C F \\
& S_{G}=\left((y 1+y 4+y 6+y 7)^{2}+(y 2+y 3+y 5+y 8)^{2}\right) / \\
& 4-C F
\end{aligned}
$$

寄与率 ${ }_{\mathrm{A}}(\%)=\left(S_{A}-f_{A} \times S e / f_{e}\right) / S_{T} \times 100 （ B \sim G$ の寄与 率も同様)

ここで, $y 1 〜 y 8$ は列番号 1 ～ 8 のデータ

$f_{A}$ は $S_{A}$ の自由度で值は “1”

$S e$ は誤差変動で $S_{A} \sim S_{G}$ の中で最も值が小さいものを誤 差と仮定する.

$f_{e}$ は $S e$ の自由度で值は“1”

実際には実験計画法のソフトが販売されているので，そ れを使えばよい。市販のソフトでは各特性值毎に入力が必 要で面倒なので，筆者は一般的な表計算ソフトの一つの行 に計算式をすべて入力して，各行にコピーすることで入力 の手間を省いている。（ご入用の方はお配りするので，連 絡いただきたく.）実験計画法の手順として，表 $3 に$ 各要 因の水準毎の特性值の平均值を, 図 1 に要因効果図の例と
して未加硫粘度の図を示す。表 4 には計算された寄与率を 一つの表にまとめたものを示す。これを寄与率表と呼ぶ. ここでひと工夫. 配合要因の水準が $1 \rightarrow 2$ に変化した際に, 特性值が増加する物についてプラスの符号を，逆に減少す る物についてマイナスの符号をつけた。配合の方向性が見 られる様にするためである。

\section{3. 二律背反の両立方法}

二律背反の例として，ゴムの硬さの向上と未加硫粘度の 低減の両立について考えてみよう。考え方としては，寄与 率の差を利用して二律背反を達成する，少しでも効果（寄 与率) が大きい特性值に対して要因を使うことで，二つの 特性值が向上することになる，理論的には，寄与率が $1 \%$ でも大きい方の特性值に対して各要因を利用することで, 最大の二律背反が実現する。実際には，寄与率が比較的大 きい要因のみを用いて設計するのがよい.その理由はまず, 寄与率も誤差を含んでいるので小さい場合は再現性が少な いこと，また，改善したい特性值はその他にもあるだろう

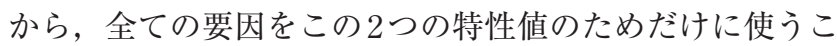
とは現実的ではないからである。

\begin{tabular}{|c|c|c|c|c|c|c|c|c|}
\hline \multicolumn{2}{|l|}{ 寄与率（\%） } & A & B & $\mathrm{C}$ & $\mathrm{D}$ & $\mathrm{E}$ & $\mathrm{F}$ & G \\
\hline 水準 1 & & A & 30 & 50 & 0 & 20 & 2 & 1 \\
\hline 水準 2 & & B & 20 & 60 & 10 & 10 & 2.5 & 1.5 \\
\hline 未加硫粘度 & ML1 + 4 & 0 & 8 & 9 & -44 & 37 & 0 & 0 \\
\hline スコーチ & ML5UP & 0 & 17 & 1 & 3 & -5 & 0 & -75 \\
\hline キュラスト & ML & -4 & 15 & 25 & -21 & 33 & 0 & -4 \\
\hline キュラスト & $\mathrm{T} 10$ & 0 & 26 & 1 & 0 & -2 & -1 & -70 \\
\hline キュラスト & T95 & 2 & 36 & 12 & -23 & 0 & -6 & -15 \\
\hline キュラスト & MH & -1 & 11 & 12 & 0 & 50 & 26 & 0 \\
\hline JIS Hardness & & 1 & 5 & 37 & 0 & 44 & 11 & 0 \\
\hline モジュラス & M300（MPa） & -1 & 1 & 18 & 0 & 61 & 18 & -2 \\
\hline 破断強度 & $\mathrm{TB}(\mathrm{MPa})$ & -8 & 0 & 21 & -47 & 9 & -11 & 0 \\
\hline 破断伸び & $\mathrm{EB}(\%)$ & -6 & -3 & -2 & -9 & -32 & -40 & 0 \\
\hline 摩耗指数 & & 8 & -36 & 0 & -16 & 4 & -32 & 0 \\
\hline
\end{tabular}

表 4 を見ると，要因 D（液状ポリマー）は，未加硫粘度 （ML1＋4）に対する寄与率が-44\%と大きいが，硬さに 対する寄与率は $0 \%$ と小さ。つまり，液状ゴムを増量す ると未加硫粘度は大きく変化するが，硬さはほとんど変化 しないことになる。ここで，未加硫粘度に対する寄与率の 符号がマイナスなので，液状ゴムを増量すると ML1 + 4 は減少することになる。つまり, 液状ゴムの増量により, ゴム硬さと未加硫粘度の二律背反が克服できることにな る. 一方, 要因 $\mathrm{E}$ (オイル) は未加硫粘度に対する寄与率 が $37 \%$ と大きいが，硬さに対する寄与率も $44 \%$ と大きく， どちらの特性值に対しても寄与率が大きいが，符号が同じ で差が少ない，つまり，硬さを向上させようとオイルを減 らせば（水準 $1 \rightarrow 2 ）$ 未加硫粘度は上昇（望ましくない方 向に変化）することになり，二律背反の解決に寄与しない。

表 4 寄与率表 
また，本例題では要因 C（カーボン）も寄与率の差が大き かった．カーボン増にて硬さが上昇する（寄与率 37\%）。 未加硫粘度も上昇するが，寄与率が小さく（9\%）少しの 粘度上昇で済む。この場合, カーボンという因子は寄与率 のより大きい，硬さという特性值の向上に用いる方が有利 である．未加硫粘度は上昇という望ましくない方向に向か うが，寄与率が小さいため，上昇は大きくはなく，全体か ら見れば二律背反が克服されたことになる。

\section{4. 実際の配合設計例}

実際の配合設計は三律背反，四律背反，いやもっと多く の特性值を両立させてゆくバランスである。この複雑な問 題の解が寄与率表から導き出せる. 優先順位の高い特性值 から，寄与率の大きい要因を使って，特性值を満足させる 様に值を決めて行けばよい，表4の寄与率表につけた符号 はここで威力を発揮する. 優先順位の高い特性值に対して 望ましい方向の配合変更が他の特性值に対して，望ましい 方向なのか, 望ましくない方向なのかが一目でわかるため, 簡単にバランス（最適化）をとることができる．実際にも う少し複雑な例を考えてみよう。

\section{例題}

現行配合（表 2 の実験番号4）の硬さは 62 であるが，向 上させたい，目標值 65 以上とする。未加硫粘度は，現行 41.7 であるが，目標 45 以下。摩耗は現行 120 であるが, $10 \%$ 向上，目標值は 132 以上とする。破断強度，伸びは 現行以上を目指す。優先順位としては硬さと未加硫粘度, 次に摩耗．破断強度と伸びとする。

そこで，寄与率表を見て硬さの向上を目指す。硬さに対 する寄与率が高い要因とその方向性は, E：オイル減, $\mathrm{C}$ ：カーボン増， $\mathrm{F}$ ：硫黄増. ただし, 寄与率表の符号か ら, E：オイル減は未加硫粘度の上昇, F : 硫黄増は摩耗 の低下を招くことがわかる．未加硫粘度の上昇に対しては $\mathrm{D}$ ：液状ポリマー増の寄与率が十分に高いことから，両立 ができそうである。しかし，F：硫黄増は硬さに対する寄 与率が $11 \%$ なに対して，摩耗に対する寄与が- $32 \%$ も るので，摩耗の悪化が大きいこともわかる．摩耗の向上も 今回の目的なので，硫黄量はなるべく増量しない方向，と いう方針が決められる。摩耗に対してはB：BR増量の効 果が高い.まとめると次のような方針となる。 B : BR増, $\mathrm{C}$ ：カーボン増, $\mathrm{D}$ ：液状ポリマー増, $\mathrm{E}$ ：オイル減そし て F : 硫黄は硬さと摩耗のレベルを見て, 達成困難な方に 使う.

次に目標值をどうやって達成してゆくかについて説明す る。要因の水準が，「配合 $\mathrm{phr}$ 」など数字で表すことので きる場合, 第一水準と第二水準の特性值で 1 次式を作って, 希望の「phr」の時の推定值を計算することができる。こ う聞くと難しく感じるかもしれないが，実際には足し算，
引き算の単純式でことが足りる。表 3 の各要因の水準ごと の特性值の平均值を利用する。例えば， BRを $5 \mathrm{phr}$ 増量 した際の未加硫粘度（ML1＋4）の变化は以下のようにな る.

$\mathrm{BR}$ 変量による変化量 $=(\mathrm{BR} 30 \mathrm{phr}$ の場合の特性值 BR $20 \mathrm{phr}$ の場合の特性值) / (実験によるBRの変量幅 phr $) \times($ BR の増加量 $\mathrm{phr})$

$$
\begin{aligned}
& =(43.80-51.38) / 10 \times 5 \\
& =-3.79
\end{aligned}
$$

同様にカーボン 5 phr増, 液状ポリマー 5 phr増, オイ ル 5 phr減も計算して，標準配合の ML1 + 4值にこれらの 変化を加えれば, 配合案 1 の物性予想值が求められる。未 加硫粘度（ML1 + 4) の場合は以下のようになる。

$$
\begin{aligned}
& 41.7+(43.80-51.38) / 10 \times 5+(51.63-43.55) \\
& / 10 \times 5+(38.98-56.20) / 10 \times 5+(39.65-55.53) \\
& / 10 \times(-5) \\
& =41.3
\end{aligned}
$$

ここで, オイルの場合，水準 $1 \rightarrow 2 て ゙ 20 \rightarrow 10$ phr と減量 している事と, 配合案 1 は標準配合から減量しているため, 符号に注意したい.すべての特性值に関して同様の計算を

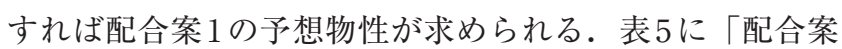
$1 」$ の予想物性を示す。表 5 には「現行配合」と目標值も 同時に示した。未加硫粘度，硬さ，破断強度は目標值を満 足したが，伸び，摩耗は目標を下回った。特に伸びが目標 值から遠い。そこで, 再度寄与率表（表4）をみて方針を 考える. 破断伸びの寄与率を見ると, 今回変量した要因の 中では，オイル（要因 $\mathrm{E} ）$ の寄与率が- $32 \%$ と大きい. オ イルを減量したため, 破断伸びが低下したことがわかる. 液状ポリマー増量も伸びの低下方向である。ちなみに BR （要因B）とカーボン（要因C）は寄与率が小さいので, 議論から省く。しかし，よく見ると伸びの寄与率は硫黄 (要因F) がー 40\%と最も高いことから, 硫黄減によって 伸びの向上が期待できる。 また, 硫黄の摩耗への寄与率 も- $32 \%$ と高く, 硫黄減によって摩耗が向上する. そこで, 配合案 2 では配合案 1 から, 硫黄を減量させる事にする。 $0.35 \mathrm{phr}$ 減量すると, 伸びが現行以上となり, 摩耗も向上, 全ての目標を達成できるため，配合案 2 を次回の試作候補 とする。ただし，これは推定值なので，確認実験として， 配合案 2 を混合してみて, 効果を確認することが大切であ る。

\section{5. 寄与率設計のポイント}

さて，この様に有効そうな寄与率設計であるが，運用に 
表5 推定値の計算

\begin{tabular}{|c|c|c|c|c|c|}
\hline & & 目標 & $\begin{array}{l}\text { 現行 } \\
\text { 配合 }\end{array}$ & $\begin{array}{l}\text { 配合 } \\
\text { 案 } 1\end{array}$ & $\begin{array}{l}\text { 配合 } \\
\text { 案 } 2\end{array}$ \\
\hline \multicolumn{2}{|l|}{ 配合 } & \multicolumn{4}{|c|}{4} \\
\hline SBR A & & & 70 & 70 & 70 \\
\hline \multicolumn{6}{|l|}{ SBR B } \\
\hline $\mathrm{BR}$ & & & 30 & 35 & 35 \\
\hline カーボン & & & 50 & 55 & 55 \\
\hline オイル & & & 20 & 15 & 15 \\
\hline 液状ポリマー & & & & 5 & 5 \\
\hline WAX & & & 2 & 2 & 2 \\
\hline $6 \mathrm{PPD}$ & & & 2 & 2 & 2 \\
\hline ステアリン酸 & & & 2 & 2 & 2 \\
\hline 酸化亜鉛 & & & 2 & 2 & 2 \\
\hline 硫黄 & & & 2 & 2 & 1.65 \\
\hline 促進剤 & & & 1 & 1 & 1 \\
\hline \multicolumn{6}{|l|}{ 未加硫物性 } \\
\hline 未加硫粘度 & $\mathrm{ML1}+4$ & 45 以下 & 41.7 & 41.3 & 42.4 \\
\hline スコーチ & ML5UP & & 20.9 & 19.2 & 19.4 \\
\hline キュラスト & $\mathrm{ML}$ & & 0.2 & 0.2 & 0.2 \\
\hline キュラスト & $\mathrm{T} 10$ & & 3.2 & 2.9 & 2.9 \\
\hline キュラスト & T95 & & 10.9 & 9.8 & 10.4 \\
\hline キュラスト & $\mathrm{MH}$ & & 1.5 & 1.8 & 1.5 \\
\hline JIS Hardness & & 65 以上 & 62 & 67 & 65 \\
\hline \multicolumn{6}{|l|}{ Tensile Test } \\
\hline モジュラス & M300 (MPa) & & 5.4 & 7.2 & 6.2 \\
\hline 破断強度 & TB（MPa） & 現行以上 & 11.4 & 11.7 & 12.3 \\
\hline 破断伸び & $\mathrm{EB}(\%)$ & 現行以上 & 513 & 461 & 514 \\
\hline 摩耗指数 & & 132 以上 & 120 & 125 & 137 \\
\hline
\end{tabular}

はいくつかのポイントがある。実験には直交実験を用い， すべての列に要因を割り付けるのが良い. 先にも述べたが， 二律背反を高いレベルで達成するためには，パラメータの 数が多いほど良い。また，実際の配合設計では達成しなけ ればならない特性值の数も多いことから，ますます要因数 が多くないと達成困難となる。

次に，検定は不要である．実験計画法では一般的に誤差 項を割り付けて，検定（主にF検定）することが一般的で ある.しかし，実験計画法を何かを設計することに用いる 場合，検定しないことをお勧めする。その理由は無駄であ るから，もし，検定結果が有意にならなかった場合，皆さ んはどうするだろうか？ 実験デー夕をすべて捨ててしま って，もう一度実験しなおすのだろうか？ 多くの場合， 費用も時間も切り詰めている状況で実験している。たとえ 有意とならなかったパラメータでも, 蒠をもすがる思いで, より性能の向上する方向で設計してテストしてみるのでは ないだろうか. それで問題ないと思う. 決して間違った設 計ではないはずである．とすれば検定結果が有意であろう が，有意でなかろうが，結果が変わらないことになり，や る意味は多くない。ただ, 実験の精度の目安になるので, 暇があったらやっておいても良い. 多くのパラメー夕（要 因）が有意になる場合，実験自体の精度が高いことの証明 となる，従って，直交実験への誤差項の割り付けは不要で ある。全ての列に配合実験をわりつければよい。寄与率を 求めるために誤差分散が必要であるが，分散が最も小さい 要因を誤差分散と考えて計算するので十分であろう。
同様に交互作用の割り付けも不要である。田口立一の 「品質工学」1）によれば, 設計は効果の大きい“主効果” で行うことで，ノイズに強い設計ができる，とある．まっ たくそのとおりである. 効果の小さい要因を使って, 少し でも性能向上を目指すことは問題ないと思うが，効果の小 さい要因のみを使って設計することは, 安定性（ロバスト 性）の意味から危険なことである. 効果の小さい要因は不 安定である．同様の考えから交互作用も同様に設計に用い るべきでない. 交互作用とはある因子の効果が別の因子の 影響で大きく変化するということである，言い換えれば非 常に不安定な効果ということになる.このような効果を用 いて設計すると, 予想した性能が使用条件によって出る場 合と出ない場合があり, 不安定となるので, やめた方が良 い. 我々はラボ実験という, 実際とは異なった製造方法で 作られたサンプルを実際の商品とは異なった条件でテスト している，そのため，実際の商品が予想の性能を発揮する ためには安定性の高い設計が必要となる.

直交実験において，交互作用を割り付けなくても交互作 用の大きさを調べる方法はある．確認実験を行うことであ る.ある実験の結果をまとめて, 確認実験（あるいは試作） を行った際に, 予想值とかけ離れた結果になった場合, 交 互作用（もしくは見落としている要因の効果）が大きかっ たと判断できる。この場合, 次の実験として交互作用を調 べる実験ではなく，交互作用のない，大きな主効果を持つ 要因を探す実験とするべきである.

\section{6. 回帰 分 析}

直交実験は回帰分析用のデータとしては非常に有用であ る. 回帰分析を行う場合, 注意すべきことの一つが疑似相 関であるが，直交実験のデータの場合，公平かつランダム なデー夕となっているため, 疑似相関が少ないからである. 相関分析をお勧めする理由は，メカニズムを解析するのに 有用だからである。各物性間の相関がクリアになると，何 が起こっているのかが考えやすい. 直交実験を行ったので あればぜひ回帰分析も行うことをお勧めする．実際に例題 を使って回帰分析を行ってみよう。表 6 にすべての特性值 間の相関係数を示す。一般的な表計算ソフトであればこの レベルの回帰分析ツールがついている，いろいろな見方が できると思うが，今回は摩耗のメカニズム解明を考えてみ たい. 表を見ると，摩耗は破断強度との相関が最も強い.

本実験はL8直交表を使っているので，デー夕数が 8 個. 重回帰分析を行うには不十分な数であるが，考え方を示す ためにやや強引に重回帰分析もしてみる。摩耗と破断強度 の関係図 2 に示す。式で表すと, 1 次回帰分析結果から, 以下のようになる。 
摩耗 $=5.52 \times$ 破断強度 $+42.5 （ r=0.47)$

相関係数がやや低い。ここで，相関係数が低いというこ とは，摩耗という現象を破断強度ではある程度しか説明で きていない，ということであるので，別のパラメータを加 えるべきである。ではどんなパラメー夕を加えればよい か？そこで，上式と摩耗との残差を計算してみる．残差 とは上式で計算した推定值と実測值の差であり，図2のデ ータの点から相関式までの距離（差）を示す．残差は，摩 耗に関して「破断強度で説明できない量」と言い換えるこ とができるので，残差と他のパラメー夕の相関を見ること で，第二変数を決めることができる．表 $7 に ， 今$ 回の残差 を含めた相関係数を示す，一番下の行に“残差”を示すが， 最も相関係数が高かったのがキュラスト MHであった。

一般的な表計算ソフトでも重回帰分析のツールがついて
いる場合がある，解析結果を表 8 に示す。これから，摩耗 が以下の重回帰式で表せることになる ${ }^{3)}$.

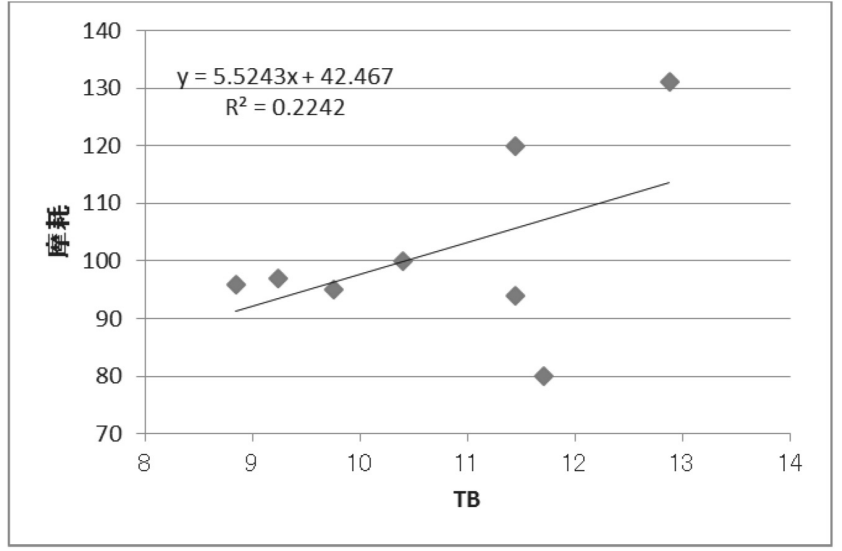

図2 残差について

表 6 相関係数一覧

\begin{tabular}{lrrrrrrrrrrr}
\hline & ML1 + 4 & ML5UP & ML & T10 & T95 & MH & Hardness & M300 & TB & EB & 摩耗 \\
\hline ML1 + 4 & 1.00 & & & & & & & & & \\
ML5UP & -0.04 & 1.00 & & & & & & & & \\
ML & 0.92 & 0.16 & 1.00 & & & & & & & \\
T10 & 0.14 & 0.98 & 0.32 & 1.00 & & & & & & \\
T95 & 0.72 & 0.53 & 0.73 & 0.69 & 1.00 & & & & & \\
MH & 0.63 & 0.02 & 0.75 & 0.08 & 0.28 & 1.00 & & & & \\
JIS Hardness & 0.61 & 0.05 & 0.73 & 0.09 & 0.34 & 0.91 & 1.00 & & & \\
M300 (MPa) & 0.63 & 0.02 & 0.75 & 0.06 & 0.23 & 0.95 & 0.93 & 1.00 & & \\
TB (MPa) & 0.77 & -0.23 & 0.73 & -0.06 & 0.49 & 0.24 & 0.29 & 0.33 & 1.00 & \\
EB (\%) & -0.21 & 0.08 & -0.27 & 0.12 & 0.09 & -0.81 & -0.79 & -0.76 & 0.27 & 1.00 & \\
摩耗指数 & 0.26 & -0.29 & 0.01 & -0.23 & 0.06 & -0.37 & -0.21 & -0.15 & 0.47 & 0.43 & 1.00 \\
\hline
\end{tabular}

表7 相関係数一覧（残差付）

\begin{tabular}{|c|c|c|c|c|c|c|c|c|c|c|c|c|}
\hline & ML1 + 4 & ML5UP & ML & T10 & T95 & $\mathrm{MH}$ & Hs & M300 & TB & $\mathrm{EB}$ & 摩耗 & 残差 \\
\hline ML1 + 4 & 1.00 & & & & & & & & & & & \\
\hline ML5UP & -0.04 & 1.00 & & & & & & & & & & \\
\hline ML & 0.92 & 0.16 & 1.00 & & & & & & & & & \\
\hline $\mathrm{T} 10$ & 0.14 & 0.98 & 0.32 & 1.00 & & & & & & & & \\
\hline T95 & 0.72 & 0.53 & 0.73 & 0.69 & 1.00 & & & & & & & \\
\hline $\mathrm{MH}$ & 0.63 & 0.02 & 0.75 & 0.08 & 0.28 & 1.00 & & & & & & \\
\hline JIS Hardness & 0.61 & 0.05 & 0.73 & 0.09 & 0.34 & 0.91 & 1.00 & & & & & \\
\hline M300 (MPa) & 0.63 & 0.02 & 0.75 & 0.06 & 0.23 & 0.95 & 0.93 & 1.00 & & & & \\
\hline $\mathrm{TB}(\mathrm{MPa})$ & 0.77 & -0.23 & 0.73 & -0.06 & 0.49 & 0.24 & 0.29 & 0.33 & 1.00 & & & \\
\hline $\mathrm{EB}(\%)$ & -0.21 & 0.08 & -0.27 & 0.12 & 0.09 & -0.81 & -0.79 & -0.76 & 0.27 & 1.00 & & \\
\hline 摩耗指数 & 0.26 & -0.29 & 0.01 & -0.23 & 0.06 & -0.37 & -0.21 & -0.15 & 0.47 & 0.43 & 1.00 & \\
\hline 残差 & -0.12 & -0.20 & -0.39 & -0.23 & -0.20 & -0.55 & -0.39 & -0.35 & 0.00 & 0.35 & 0.88 & 1.00 \\
\hline
\end{tabular}

表8 重回帰分析結果

SUMMARY OUTPUT

\begin{tabular}{lc}
\hline Regression & Statistics \\
\hline Multiple R & 0.688658 \\
R Square & 0.47425 \\
Adjusted R & 0.26395 \\
Standard E & 13.85607 \\
Observatio & 8 \\
\hline
\end{tabular}

ANOVA

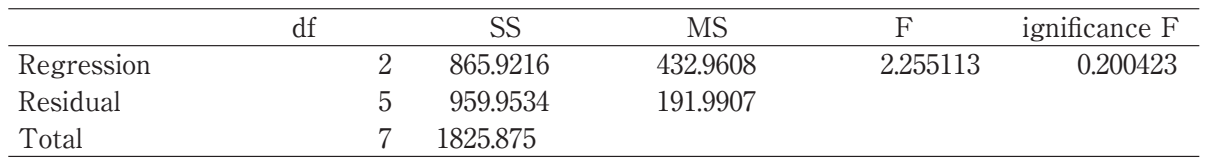

\begin{tabular}{lcccccccc}
\hline & Coefficients & Standard Error & t Stat & P-value & Lower 95\% & Upper 95\% & Lower 95.0\% & Upper 95.0\% \\
\hline Intercept & 74.36768 & 45.74985 & 1.625529 & 0.164978 & -43.236 & 191.9714 & -43.236 & 191.9714 \\
TB (MPa) & 6.987998 & 3.900149 & 1.791726 & 0.133169 & -3.03766 & 17.01365 & -3.03766 & 17.01365 \\
MH & -22.4095 & 14.53316 & -1.54196 & 0.183723 & -59.7682 & 14.94915 & -59.7682 & 14.94915 \\
\hline
\end{tabular}


表9 重回帰分析結果（INDEX）

SUMMARY OUTPUT

\begin{tabular}{lc}
\hline Regression & Statistics \\
\hline Multiple R & 0.688658 \\
R Square & 0.47425 \\
Adjusted R & 0.26395 \\
Standard E & 13.63451 \\
Observatio & 8 \\
\hline
\end{tabular}

ANOVA

\begin{tabular}{|c|c|c|c|c|c|}
\hline & & SS & MS & $\mathrm{F}$ & ignificance $\mathrm{F}$ \\
\hline Regression & 2 & 838.4505 & 419.2253 & 2.255113 & 0.200423 \\
\hline Residual & 5 & 929.4993 & 185.8999 & & \\
\hline Total & 7 & 1767.95 & & & \\
\hline
\end{tabular}

\begin{tabular}{lcccccccc}
\hline & Coefficients & Standard Error & t Stat & P-value & Lower 95\% & Upper 95\% & Lower 95.0\% & Upper 95.0\% \\
\hline Intercept & 73.17853 & 45.0183 & 1.625529 & 0.164978 & -42.5447 & 188.9018 & -42.5447 & 188.9018 \\
TB (MPa) & 0.736361 & 0.410979 & 1.791726 & 0.133169 & -0.32009 & 1.792816 & -0.32009 & 1.792816 \\
MH & -0.46815 & 0.303605 & -1.54196 & 0.183723 & -1.24859 & 0.312296 & -1.24859 & 0.312296 \\
\hline
\end{tabular}

摩耗 $=7.00 \times$ 破断強度 $-22.4 \times \mathrm{MH}+74.4 \quad(r=0.69)$

本例題は架空のデータであるので，メカニズムを議論す ることはできないが, 摩耗という現象を破断強度とキュラ スト（MH）で説明できたことになる，例えば，破断強度 は向上するほど摩耗は良くなるが，MHは低下するほどよ い. 力を逃がすようなメカニズムが摩耗に有利なのかもし れない。また，モジュラスでなく，MHに相関があったこ とで，摩耗の変形モード，あるいは歪率が $\mathrm{MH}$ に近いのか もしれない, という考察ができるかもしれない.ここで, もう一度一工夫. この重回帰分析のすべてのデータを平均 值を 100 としたINDEXにて分析しなおしてみる（表9）.

摩耗 $=0.73 \times$ 破断強度 $\times 0.47 \times \mathrm{MH}+73.18(r=0.69)$

仮にこの式の破断強度，と MHの今回の変動幅の “重み” が同じであるとすると，係数が寄与の比となる．寄与率\% に，計算しなおすと以下の様である。

破断強度の寄与率 $=0.73 /(0.73+0.47) \times 100=61 \%$

$\mathrm{MH}$ の寄与率 $=0.47 /(0.73+0.47) \times 100=39 \%$

破断強度の方が摩耗に対する寄与率が高いことがわか る. 物の設計をする場合は何の相関が高いかも重要である が, どのパラメータの効果が大きいか, 寄与率を考慮する 必要がある。

\section{7. ま め}

ゴムの配合実験から配合設計を行う際に，直交実験を用
いた実験を行い，各要因の寄与を見ることで，効率よく性 能の両立・バランスが達成できることを説明した。また， 直交実験を用いたデー夕は回帰分析に適している。回帰分 析を行うことで, 物理現象のメカニズム解明のヒントとな ることも説明した．少し強引ではあったが，重回帰分析の 進め方も説明した。 日頃, 配合実験を行って配合設計を行 っている読者の方々の参考になれば幸いである.

今回は性能の向上をターゲットとして説明したが，特性 值に「コスト」を入力すればコストと性能の両立も可能で ある. 単価の高い配合剤は当然コストに対する寄与率が大 きくなるが, 性能とのバランスを寄与率という数字で表す ことができる，安い配合剤の組み合わせで，高価な配合剂 の性能を補完できる事がわかったり, 高価な配合剂でも性 能の向上に寄与していれば使うという判断も可能となった りする. 日頃コストダウンに取り組んでいる方にも試して いただきたい。

\section{References}

$1)$ Taguchi, G.: "Hinshitsu Kogaku Koza 1 Kaihatsu Sekkei Dankai No Hinshitsu Kogaku”, Nippon Kikaku Kyokai, Tokyo, Chapter 4, 5 and 6 (1988)

2 ) Taguchi, G.: “Jikken Keikakuhou Jo (3rd ed.)”, Maruzen, Tokyo, Chapter 1 (1976)

3 ) Suga, T.: "Excel De Manabu Tahenryo Kaiseki Nyumon", Omu, Tokyo, Chapter 7 (2007)

\section{日本語表記参考文献}

1 ) 田口玄一：品質工学講座 1 開発・設計段階の品質工学, (財) 日本規格協会，東京，第 4 章，第 5 章，第 6 章（1988）

2 ) 田口玄一: 実験計画法 上, 第 3 版, 丸善株式会社, 東京, 第 1 章 (1976)

3 ）菅民郎：Excelで学ぶ多変量解析入門, オーム社, 東京, 第7章 (2007) 